\title{
Technology indicators: population, labour and schooling : 1991 report
}

Citation for published version (APA):

van Dam, J. W., Lodder, B. J. H., \& Ramaekers, G. W. M. (1991). Technology indicators: population, labour and schooling : 1991 report. Researchcentrum voor Onderwijs en Arbeidsmarkt, Faculteit der Economische Wetenschappen. ROA Reports No. 9E https://doi.org/10.26481/umarep.199109E

Document status and date:

Published: 01/01/1991

DOI:

10.26481/umarep.199109E

Document Version:

Publisher's PDF, also known as Version of record

\section{Please check the document version of this publication:}

- A submitted manuscript is the version of the article upon submission and before peer-review. There can be important differences between the submitted version and the official published version of record.

People interested in the research are advised to contact the author for the final version of the publication, or visit the DOI to the publisher's website.

- The final author version and the galley proof are versions of the publication after peer review.

- The final published version features the final layout of the paper including the volume, issue and page numbers.

Link to publication

\footnotetext{
General rights rights.

- You may freely distribute the URL identifying the publication in the public portal. please follow below link for the End User Agreement:

www.umlib.nl/taverne-license

Take down policy

If you believe that this document breaches copyright please contact us at:

repository@maastrichtuniversity.nl

providing details and we will investigate your claim.
}

Copyright and moral rights for the publications made accessible in the public portal are retained by the authors and/or other copyright owners and it is a condition of accessing publications that users recognise and abide by the legal requirements associated with these

- Users may download and print one copy of any publication from the public portal for the purpose of private study or research.

- You may not further distribute the material or use it for any profit-making activity or commercial gain

If the publication is distributed under the terms of Article $25 \mathrm{fa}$ of the Dutch Copyright Act, indicated by the "Taverne" license above, 
TECHNOLOGY INDICATORS: POPULATION, LABOUR AND SCHOOLING

- 1991 Report -

ROA-R-1991/9E

J.W. van Dam

B.J.H. Lodder

G.W.M. Ramaekers

RESEARCH CENTRE FOR EDUCATION AND THE LABOUR MARKET

Faculty of Economic Sciences

Rijksuniversiteit Limburg

Maastricht, December 1991 


\section{CIP-GEGEVENS KONINKLIJKE BIBLIOTHEEK, DEN HAAG}

Dam, J.W. van

Technology indicators: population, labour and schooling: 1991 report / J.W. van Dam, B.J.H. Lodder, G.W.M. Ramaekers ; [transl. from the Dutch]. - Maastricht : Research Centre for Education and the Labour Market, Faculty of Economic Sciences, Rijksuniversiteit Limburg. (Report / Research Centre for Education and the Labour Market, ISSN 0922-8098; 1991/9E) Vert. van: Technologie-indicatoren: bevolking, arbeid en scholing: rapportage 1991. - Maastricht : Researchcentrum voor Onderwijs en Arbeidsmarkt, Faculteit der Economische Wetenschappen, Rijksuniversiteit Limburg, 1991. - (Rapport / Researchcentrum voor Onderwijs en Arbeidsmarkt, ISSN 0922-8098; 1991/9). - Met lit. opg. ISBN 90-5321-076-8 geb.

Trefw.: onderwijs en arbeidsmarkt ; Nederland 


\section{CONTENTS}

\section{TABLES AND FIGURES}

ACKNOWLEDGEMENT

1. INTRODUCTION

2. KEY INDICATORS UPDATED 2

2.1. Introduction 2

2.2. Initial education 3

2.2.1. Dual education 3

2.2.2. Share of vocational education in total regular education 4

2.3. The need for training 5

2.3.1. Labour-market situation for the technically educated: tension indicators 5

2.3.2. Age composition of the (active) population and dependency rate 6

2.4. Educational efforts 11

2.4.1. Proportion of the potential labour force in post-elementary education

2.4.2. Proportion of apprenticeships in the labour volume of industrial sectors

3. RESPONSE FROM ASSOCIATED INSTITUTES AND COMPLEMENTARY DATA SOURCES

3.1. Mailing and response from the network 14

3.2. European institutes and the integration of data collection 14

3.3. Incidental surveys $\quad 15$

$\begin{array}{ll}\text { 3.3.1. Command of foreign languages } & 15\end{array}$

3.3.2. Unemployment and participation in education among young people in Europe

3.3.3. IRDAC report on skill shortages in Europe $\quad 22$

$\begin{array}{ll}\text { 3.3.4. Job mobility } & 23\end{array}$

4. CONCLUSIONS 25

$\begin{array}{ll}\text { LITERATURE } & 27\end{array}$

APPENDIX I : CLASSIFICATION OF INDUSTRIAL SECTORS 29

APPENDIX II: PUBLICATIONS RECEIVED, BY COUNTRY 30 


\section{TABLES AND FIGURES}

Key indicators:

Table 1 : Proportion of dual-system students in total population between the ages of 15 and 24.

Table 2 : Indicator of the share of vocational education (second and third levels).

Table 3 : Unemployment rates among schoolleavers (May figures).

Table 4 : Percentage shares of age groups in total population.

Table 5 : Percentage shares of age groups in active population.

Table 6 : Development of the dependency rate in 7 industrial countries.

Figure 1 : Dependency rate in the $12 \mathrm{EC}$ member states: 1985, 2025

Table 7 : Participation in schooling of the potential labour force between the ages of 15 and 49 (in the wide sense).

Table 8 : Participation in schooling of the potential labour force between the ages of 15 and 49 (in the narrow sense).

Table 9 : Percentage share of primary apprenticeships in labour volume of industrial sectors.

Table 10 : Percentage share of secondary apprenticeships in labour volume of industrial sectors.

Command of foreign languages:

Table 11 : Dutch exports, divided by language regions (percentages).

Table 12 : Need for foreign languages in Dutch enterprises (percentages).

Table 13a : Percentage of businessmen with some degree of mastery of English, French or German.

Table 13b : Percentage shares of English, French and German in the languages mastered, to some degree, by businessmen.

Table 14 : Problems experienced in Dutch enterprises in using English, French and German (percentages).

Table 15 : Number of foreign languages learned at school and correctly spoken.

Unemployment and participation in education among young people in Europe:

Figure 2 : Percentage shares of age groups in education in the EC

Table 16 : Unemployment rates among 14 to 24 year olds in the EC.

Figure 3 : Unemployment rates among 14 to 24 year olds in the EC.

IRDAC report on skill shortages in Europe:

Table 17 : Indicators of the relative importance of engineering and exact sciences in university education and the proportion of engineers in active population.

Figure 4 : Expected demand for educational groups.

Job mobility:

Table 18 : Percentage share of workers who change jobs, under high demand, low unemployment, labour market conditions 


\section{ACKNOWLEDGEMENT}

This study was commissioned by the Dutch Ministry of Economic Affairs, Directorate for General Technology Policy. It has been carried out by Drs J.W. van Dam, Drs B.J.H. Lodder and Drs G.W.M. Ramaekers (project leader), assisted by P. Ghijsen.

It was the third study carried out by the ROA in the framework of a databank for technology policy, 'METING'. The first was performed in 1989 by $\operatorname{Dr}$ A. de Grip and Mrs Drs W.J. Nusselder, and described in the ROA-report 'Technology Indicators referring to Education and Labour' (ROA-R-1989/4E). The second study was carried out in 1990 by Drs J.W. van Dam and Dr A. de Grip. It was described in the ROA-report 'Technology Indicators: Population, Labour and Schooling' (ROA-R-1990/5E).

The report now lying before you is a follow-up to the previous ones. Chapter 2 describes the updating of five of the six key indicators developed in 1989, followed by a brief interpretation. In chapter 3 an international inventory of figures on population, labour and training that may be relevant to technology policy is presented. The report starts with an introduction in chapter 1 and is rounded off by a short evaluation and some recommendations in chapter 4 .

In addition to this the Dutch version of this report also includes two case studies, on the match between education and the labour market in Sweden and the participation of women in technical training and occupations. 


\section{INTRODUCTION}

The report METING 2, Indicatoren voor de technologische positiebepaling van Nederland (Ministry of Economic Affairs, 1990) explained the organisation and objectives of the databank for indicators of technology 'METING' ('MEASUREMENT'). One category of indicators refers to the technological potential of the labour force as an indication of the breeding ground for technological development. In 1990 it was decided that the Research Centre for Education and Labour Market (ROA) should focus on six selected internationally comparable 'key indicators' of labour and training (see Van Dam and de Grip, 1990): relative participation in dual education, the share of vocational education in total regular education, the share of technically skilled people in the total number of schoolleavers and in the labour force, the labour-market situation for the technically skilled, the age composition of the (economically active) population, and the portion of the labour force enrolled in training courses. This year's study consists of two parts. The first part concerns the updating of the key indicators of the societal breeding ground for technological innovations, mostly on the basis of international statistical data sources of ILO, UNESCO, Eurostat, and OECD. In addition the network of foreign statistical offices was approached with a view to completing the existing key indicators and to explore the possibility of developing new indicators of population, labour and schooling. This network consists of some 60 statistical offices, research institutes and/or researchers in the Netherlands, West Germany, France, the United Kingdom, Sweden, the United States, and Japan. In this report West Germany refers to the former 'Bundesrepublik Deutschland' before the reunification in 1990.

The relation between technological development on the one hand and education and labour on the other is one of mutual influence. For one thing, the training of the labour force is an important determinant of a country's Research \& Development capacity. The degree of skill of the labour force thus influences the innovative capacity of the society. On the other hand, technological progress has a tremendous impact not only on the growth of the national economy and the shifts in the economic structure, but also on the volume and composition of employment, the contents of functions, the demand for certain skills, and hence the nature and level of the training required. In this respect, the degree of skill the labour force possesses is an important determinant of the diffusion potential of technological progress.

Chapter 2 presents the updated key indicators. The classification is broadly the same as in last year's report. Chapter 3 displays the results of the search for additional data concerning population, labour and schooling in a selection of industrialised countries. A brief evaluation and some recommendations complete the report. 


\section{KEY INDICATORS UPDATED}

\subsection{Introduction}

This year's attention is focused on updating five 'key indicators' of the societal breeding ground for technological advance: relative participation in dual education, the share of vocational education in total regular education, the labour-market situation for the technically skilled, the age composition of the (economically active) population, and the portion of the labour force enrolled in training courses. The 1990 report also included a sixth key indicator, namely the share of technically skilled people in the total number of schoolleavers and in the labour force. This year it proved to be impossible to update this indicator in time since the annual SKILL forecasts of the Dutch Ministry of Education, which formed the basis for updating this indicator, have been replaced from this year on by the "Referentie Raming" from the Ministry of Education. The release date for this forecast was so late that ROA could not properly incorporate it. The most recently updated version of this indicator is therefore to be found in the 1990 report.

Also this year's study on technology indicators consists of two parts. The first part concerns the updating of the key indicators, mostly on the basis of international statistical data sources of ILO, UNESCO, Eurostat, and OECD. The results are presented in this chapter. In addition the network of foreign statistical offices was approached in order to complete the existing key indicators and to develop new indicators. The statistical offices, research institutes and/or researchers of this network were asked to provide relevant data or reports. The results of this network approach are discussed in chapter 3.

As mentioned in the 1990 report the key indicators have to satisfy the following conditions. They should be relevant to the various aspects of the General Technology Policy as well as practible. Input and output indicators should balance each other more or less. Some indicators should give an insight into the societal aspects of technological advance. For the sake of international comparison, indicators should be feasible for other countries as well. Finally, the data sources underlying the indicators should guarantee some degree of continuity. Especially the conditions of international comparability and continuity have drawn full attention in writing this year's report as well as previous reports.

In presenting the updated key indicators in this chapter broadly the same classification is used as last year. Section 2.2 discusses two indicators of the contribution of initial education to the future breeding ground for technological advance, namely the relative participation in dual education and the share of vocational education in total regular education. Section 2.3 presents two indicators measuring the necessity of training to overcome present or possible future impediments to the further diffusion of technological progress. These indicators are the labourmarket situation for the technically skilled and the age composition of the (economically active) population. This indicator has been extended this year by calculating the associated dependency rate. Finally, Section 2.4 presents two indicators of the training efforts being made in response 
to such obstacles, namely the proportion of the labour force enroled in training courses and the number of apprenticeship agreements per sector, expressed as a proportion of the labour volume of the sector. The second of these is included here for the first time this year.

\subsection{Initial education}

\subsubsection{Dual education}

Dual education is the collective name for types of education that combine learning and working, thus providing the students with basic skills for their future careers. In the Netherlands, most dual education takes the form of apprenticeship. The participation of young people in dual education, as already pointed out in De Grip and Nusselder (1989), can be considered indicative of the scientific and technological breeding ground for, in particular, the diffusion of technological advance.

The number of students in dual education can be calculated from the results of the Labour Force Survey (1983-1989) of the European Community. In that survey, persons between the ages of 15 and 50 were asked to state the type and purpose of any training course 1 they had been engaged in during four weeks preceding the survey. Like last year, we related the number of persons participating in dual education to ILO-figures of the total number of persons in the 15-24 age bracket. This makes a comparison among countries possible.

Table 1. Proportion of dual-system students in total population between the ages of 15 and 24

\begin{tabular}{lccccccc}
\hline & $\begin{array}{c}1983 \\
\%\end{array}$ & $\begin{array}{c}1984 \\
\%\end{array}$ & $\begin{array}{c}1985 \\
\%\end{array}$ & $\begin{array}{c}1986 \\
\%\end{array}$ & $\begin{array}{c}1987 \\
\%\end{array}$ & $\begin{array}{c}1988 \\
\%\end{array}$ & $\begin{array}{c}1989 \\
\%\end{array}$ \\
\hline The Netherlands & 2.5 & 2.4 & 2.3 & 2.3 & 2.3 & 1.9 & 1.7 \\
France & 2.6 & 2.6 & 2.5 & 2.4 & 2.6 & 2.8 & 2.9 \\
(West) Germany & 10.0 & 13.5 & 15.5 & 17.7 & 17.4 & 17.7 & 17.5 \\
United Kingdom & 7.6 & 5.0 & 5.6 & 4.8 & 4.9 & 5.3 & 5.7 \\
Italy & 0.5 & 0.6 & 0.5 & 0.6 & 0.6 & 0.6 & 0.8 \\
Belgium & 2.3 & 1.9 & 1.8 & 1.9 & 1.6 & 1.3 & 1.5 \\
Luxemburg & 5.8 & 6.3 & 7.0 & 6.1 & 5.7 & 5.1 & 4.8 \\
Ireland & 2.8 & 2.2 & 2.5 & 2.0 & 1.9 & -- & 2.0 \\
Denmark & 7.4 & 18.8 & 22.1 & 22.7 & 23.7 & 23.8 & 20.4 \\
Greece & 0.3 & 0.3 & 0.4 & 0.5 & 0.3 & 0.3 & 0.3 \\
\hline
\end{tabular}

Source: Eurostat/ILO/ROA

The data of table 1 may be slightly distorted by shifts in the non-response of the survey, and should therefore be interpreted with some caution. Nevertheless the fact transpires clearly that

1. This survey makes a distinction between "apprenticeship" (learning contract) and other types of dual education. 
dual education despite the slight decrease of the 1989 percentage remains much more important in Denmark and West Germany than in the other countries investigated. The Netherlands are clearly at the lower end of the scale. The decrease of the percentage for the Netherlands which started in 1988 continues in 1989. By contrast, in Italy and Belgium a slight increase can be observed in 1989. The slight recovery which started in the second half of the eighties in France and the United Kingdom continues in 1989. By contrast, in Luxembourg the declining tendency noticeable after 1985 continues in 1989. Ireland and Greece show a stable low picture. For the time being this indicator is only available for the EC countries.

\subsubsection{Share of vocational education in total regular education}

This sub-section's indicator represents the share of vocational students (second and third levels2) in the total number of second- and third-level students. On the basis of the Statistical Yearbook of Unesco (1983-1988) a division into vocational and general education is possible. To compose the indicator we have counted all third-level education (Higher Education) as vocational education.

Table 2. Indicator of the share of vocational education (second and third levels)

\begin{tabular}{lcccccccccc}
\hline & $\begin{array}{c}1975 \\
\%\end{array}$ & $\begin{array}{c}1980 \\
\%\end{array}$ & $\begin{array}{c}1981 \\
\%\end{array}$ & $\begin{array}{c}1982 \\
\%\end{array}$ & $\begin{array}{c}1983 \\
\%\end{array}$ & $\begin{array}{c}1984 \\
\%\end{array}$ & $\begin{array}{c}1985 \\
\%\end{array}$ & $\begin{array}{c}1986 \\
\%\end{array}$ & $\begin{array}{c}1987 \\
\%\end{array}$ & $\begin{array}{c}1988 \\
\%\end{array}$ \\
\hline The Netherlands & 51 & 53 & 53 & 54 & 55 & 55 & 56 & 57 & 57 & -- \\
France & 35 & 36 & 36 & 40 & 38 & 39 & 36 & 40 & 38 & 39 \\
(West) Germany & 32 & 33 & 35 & 37 & 29 & 31 & 32 & 48 & 49 & 50 \\
United Kingdom & 16 & 18 & 19 & 19 & 20 & 23 & 24 & 26 & 27 & -- \\
Sweden & 45 & 45 & 46 & 49 & 51 & 51 & -- & 50 & 50 & 51 \\
Austria & 25 & 33 & 33 & 35 & 37 & 40 & 41 & 43 & 43 & 44 \\
United States & -- & -- & -- & -- & -- & -- & -- & -- & -- & -- \\
Japan & 34 & 32 & 32 & 30 & 30 & 29 & 28 & 28 & 28 & 29 \\
\hline
\end{tabular}

Source: UNESCO $(1984,1985,1986,1987,1988,1989)$

Legend: $--=$ not available

The vocational/general ratio indicates in particular the degree to which people in their later careers are open to technological advance. The underlying assumption is that workers with a broad initial vocational education tend to be more responsive to innovations than workers who have gained their skill in practice; the latter tend in particular to fall short on theoretical knowledge. Therefore, this indicator can be considered representative of the scientific and technological breeding ground for the diffusion of technological change. Possibly a higher share of vocational education can also be considered to add to the society's innovative potential.

Table 2 shows that the Netherlands, Sweden and West Germany have a high proportion of students in vocational education, whereas in the United Kingdom and Japan it is much lower. In

2. The second and third levels comprise all education beyond the elementary stage. 
the Netherlands and Sweden the indicator remains at a stable high level. In most countries, particularly in West Germany, the United Kingdom and Austria, this indicator. shows a rising tendency. It seems that the steadily declining tendency in Japan came to an end in 1988.

\subsection{The need for training}

\subsubsection{Labour-market situation for the technically educated: tension indicators}

Van Paridon has developed an indicator of bottlenecks on the labour market for technically educated persons representing the proportion of schoolleavers of the most recent cohort who are still unemployed (see De Grip and Heijke, 1988). It relies on unemployment figures of the District Labour Exchanges, corrected for "file corruption"3. The indicator thus obtained is, as said before, a criterion by which to identify obstacles to the diffusion of technological advance in certain segments of the labour market.

Table 3. Unemployment rates among schoolleavers (May figures)

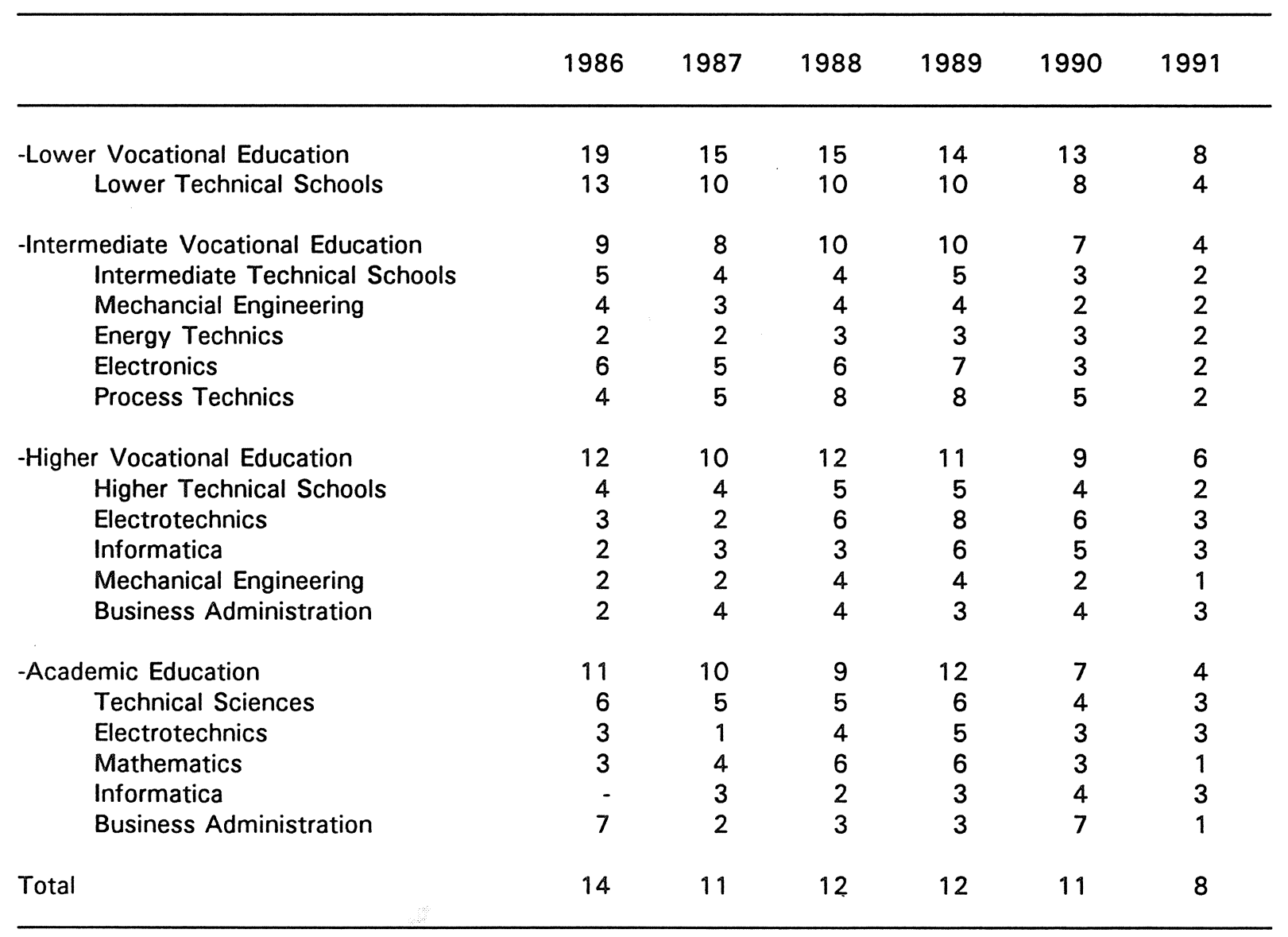

Source: Van Paridon/ROA

3. Following Van Paridon we assume that the file corruption among schoolleavers is great (60 per cent), because many remain on the registers while working in temporary jobs, whether or not acquired through an employment agency. 
Table 3 displays the employment situation in the years between 1986 and 1991. As can be observed, the decline in unemployment after 1989 continued in 1991. In 1991, in this tightening but still relatively easy general labour market, the situation for those with a technical education has become even tighter. That points to an improvement in the labour-market position of those with a non-technical education. In particular unemployment among nontechnical university graduates has declined further since 1989. One striking fact is the improvement in the labour market situation of university-educated commerce graduates, which has become very favourable to work seekers in 1991.

Regrettably, no internationally comparable data could be traced in any publications of international organisations or national statistic bureaus.

\subsubsection{Age composition of the (active) population and dependency rate}

Two indicators represent the age composition of, respectively, total population and the economically active population (labour force)4. These indicators measure the declining share of the young and the increasing share of the aged in, respectively, the total and the economically active population. To comply with the wishes of the Ministry of Economic Affairs, we will give an overall picture of the age composition of the (active) population rather than specific indicators of either share.

The share of 'senior citizens' in the active population can be considered a measure of the need for training on the assumption that, as technological progress renders the labour force's initial training obsolete, retraining becomes necessary to the productive re-employment of the workers involved. In other words: the indicator measures the "vulnerability" of the labour force to technological progress. It is also a measure of the "intra-generational mobility5" required to overcome any shifts which technological advance should cause in the occupational structure. The drop in the proportion of young people $(15-24)$ in the active and overall population indicates the society's ability to respond to the changed educational requirements due to technological progress by adjusting initial education to practical demands. Indeed, the adjustment of initial education to the developments on the labour market will have less effect as the proportion of young people in the labour force is lower.

Table 4 shows the size of the four age groups distinguished as proportions of the total population. It shows that a low proportion of young people is especially to be found in Sweden. In the United States however, the proportion of young people is dropping at the fastest rate. In contrast, Austria and Japan are experiencing a growing proportion of young people.

4. The ILO defines the economically active population as all persons providing the supply of labour for the production of goods and services. Both employed and unemployed persons belong to the active population (ILO, 1989). Students, retired persons and women not participating in the labour market, on the contrary, do not come under the definition.

5. A. de Grip, Onderwijs en Arbeidsmarkt: Scholingsdiscrepanties, Amsterdam, 1987. 
The population of West Germany in particular is marked by a relatively large group of over-50s. Japan, however, experienced the fastest increase in the older age groups in the 1980s.

Table 5 represents the shares of the same four age groups in the economically active population. From this table, the United States, Austria, West Germany, the Netherlands and the United Kingdom have a relatively young active population, whereas in Japan the share of the over-65 in the active population is relatively high. A striking feature is the relatively high proportion of active people between the ages of 50 and 65 in Japan and Sweden. That group's share even increased in Japan in the course of the 1980s. The lowest proportion of people between the ages of 50 and 65 in the active population is found in the Netherlands and Austria where moreover it declined considerably in the 1980s. The same pattern, though somewhat subdued, applies to most other countries.

The 1990 report also included forecasts of the future share of senior citizens in the Dutch (potential) labour force. Last year such forecasts have been drawn up for the age structures of the total population and the potential labour force (between the ages of 15 and 65) in the Netherlands. The forecasts neatly showed the expected declining proportion of the younger age brackets and the expanding share of the older ones. It was calculated that the proportion of young people (between 15 and 24 years old) in the potential labour force is expected to drop from 23.0 per cent in 1990 to only 17.4 per cent in 2005, after which it is expected to increase again slightly. By contrast, a clear increase in the share of the older age brackets (1565 ) in the potential labour force is perceived: from 21.2 per cent in 1990 to 28.0 per cent in 2005. Presumably, the process of aging will continue to around 2030.

The dependency rate is the sum of the percentage shares of children (0-14 years old) and of senior citizens (over-65). These age groups together form the non-productive part of the population. The dependency rate indicates the labour productivity which is required from the active population and the technological advance required to ensure this labour productivity. Table 6 shows changes in the dependency rate in seven industrialized countries. The figures from 1990 to 2020 are extrapolations, calculated on the basis of the previous five-year periods. The data were obtained from the 'World Population Prospects 1990', from the United Nations.

The overall development from table 6 can be summarized as follows. After an increase in the 1950 s, probably as a result of the post-war baby boom, the dependency rate decreases in the 60s, 70s and 80s. From 1990 on the trend changes to an increase which is expected to last into the next century. The increase will be considerable, especially in West Germany and Japan. At present, the dependency rate is relatively low in the Netherlands, West Germany, the United States and Japan. In interpreting the low rate in the Netherlands it should be stressed that the participation of women in employment is also low. Figure 1 displays the changes in the 12 EC member states. The figure shows that in the year 2025, as compared with 1985, the dependency rate will have increased substantially, mainly due to the aging of the population. This European picture does not apply to Ireland and the two countries of the Iberian peninsula, who at present have a relative young population structure and hence expect a decrease in the dependency rate. 
$-8-$

Table 4. Percentage shares of age groups in total population

\begin{tabular}{|c|c|c|c|c|c|c|c|c|c|c|c|}
\hline & age & $\begin{array}{c}1980 \\
\%\end{array}$ & $\begin{array}{c}1981 \\
\% \\
\end{array}$ & $\begin{array}{c}1982 \\
\% \\
\end{array}$ & $\begin{array}{c}1983 \\
\% \\
\end{array}$ & $\begin{array}{c}1984 \\
\% \\
\end{array}$ & $\begin{array}{c}1985 \\
\% \\
\end{array}$ & $\begin{array}{c}1986 \\
\%\end{array}$ & $\begin{array}{c}1987 \\
\%\end{array}$ & $\begin{array}{c}1988 \\
\% \\
\end{array}$ & $\begin{array}{c}1989 \\
\%\end{array}$ \\
\hline \multirow[t]{4}{*}{ The Netherlands } & $15-24$ & 17.3 & 17.4 & 17.4 & 17.3 & 17.3 & -- & 17.2 & 16.9 & -- & -- \\
\hline & $25-49$ & 34.2 & 34.5 & 35.2 & 35.2 & 35.1 & -- & 36.5 & 37.2 & -- & -- \\
\hline & $50-65$ & 14.4 & 14.5 & 14.5 & 14.6 & 14.6 & -- & 14.7 & 14.7 & - & -- \\
\hline & $65+-$ & 11.5 & 11.6 & 11.7 & 11.7 & 11.7 & -- & 12.2 & 12.5 & -- & -- \\
\hline \multirow[t]{4}{*}{ France } & $15-24$ & 15.9 & 15.8 & 15.7 & 15.6 & 15.6 & 15.6 & 15.5 & 15.1 & 15.9 & -- \\
\hline & $25-49$ & 33.3 & 33.4 & 33.5 & 33.7 & 33.3 & 34.1 & 34.4 & 35.0 & 35.9 & -- \\
\hline & $50-65$ & 15.3 & 15.8 & 16.2 & 16.6 & 16.7 & 16.5 & 16.4 & 16.4 & 15.8 & -- \\
\hline & $65+-$ & 14.5 & 14.2 & 13.9 & 13.7 & 13.4 & 13.7 & 13.9 & 13.8 & 14.9 & -- \\
\hline \multirow[t]{4}{*}{ (West) Germany } & $15-24$ & 15.6 & 16.1 & 16.3 & 16.7 & 16.7 & 16.5 & 16.3 & 15.7 & 15.0 & -- \\
\hline & $25-49$ & 34.1 & 34.2 & 34.4 & 35.3 & 35.2 & 35.2 & 35.4 & 35.6 & 35.6 & -- \\
\hline & $50-65$ & 16.2 & 16.6 & 17.1 & 17.3 & 18.1 & 18.4 & 18.4 & 18.6 & 18.9 & -- \\
\hline & $65+-$ & 15.9 & 15.6 & 15.4 & 14.2 & 15.0 & 15.2 & 15.4 & 15.7 & 16.0 & -- \\
\hline \multirow[t]{4}{*}{ United Kingdom } & $15-24$ & -- & 15.8 & - & -- & -- & -- & 16.3 & -- & -- & -- \\
\hline & $25-49$ & - & 31.8 & -- & -- & -- & -- & 33.2 & -- & -- & -- \\
\hline & $50-65$ & -- & 16.8 & -- & -- & -- & -- & 16.2 & -- & -- & -- \\
\hline & $65+-$ & -- & 14.8 & -- & -- & -- & -- & 15.3 & -- & -- & -- \\
\hline \multirow[t]{4}{*}{ Sweden } & $15-24$ & 12.0 & -- & 12.3 & 12.5 & 12.6 & 12.6 & 12.6 & 12.7 & -- & -- \\
\hline & $25-49$ & 33.4 & -- & 33.7 & 34.0 & 34.2 & 34.4 & 34.3 & 34.8 & -- & -- \\
\hline & $50-65$ & 17.3 & -- & 17.0 & 16.8 & 16.6 & 16.3 & 16.2 & 15.7 & -- & -- \\
\hline & $65+-$ & 16.6 & -- & 10.0 & 9.9 & 9.9 & 10.0 & -- & -- & -- & - \\
\hline \multirow[t]{4}{*}{ Austria } & $15-24$ & 14.4 & 16.7 & 16.7 & 16.6 & 17.0 & 16.9 & 16.7 & 16.3 & 15.9 & -- \\
\hline & $25-49$ & 34.0 & 32.3 & 32.6 & 33.3 & 33.5 & 34.0 & 34.6 & 35.3 & 35.9 & -- \\
\hline & $50-65$ & 15.6 & 15.8 & 16.2 & 16.5 & 16.7 & 16.6 & 16.3 & 16.0 & 15.8 & -- \\
\hline & $65+-$ & 15.5 & 15.2 & 14.9 & 14.4 & 14.3 & 14.4 & 14.5 & 14.7 & 14.9 & -- \\
\hline \multirow[t]{4}{*}{ United States } & $15-24$ & 16.9 & 17.3 & 19.5 & -- & 17.0 & 16.6 & 16.2 & 15.7 & 15.2 & 13.5 \\
\hline & $25-49$ & 32.4 & 33.2 & 33.9 & -- & 35.1 & 35.8 & 36.4 & 37.0 & 37.4 & 38.1 \\
\hline & $50-65$ & 14.7 & 14.6 & 14.4 & -- & 14.1 & 13.9 & 13.7 & 13.5 & 13.4 & 13.4 \\
\hline & $65+-$ & 11.2 & 11.4 & 11.6 & -- & 11.9 & 11.9 & 12.1 & 12.3 & 12.4 & 12.6 \\
\hline \multirow[t]{4}{*}{ Japan } & $15-24$ & 13.8 & 13.6 & 13.7 & 13.8 & 14.0 & 14.2 & 14.4 & 14.7 & 15.0 & 15.2 \\
\hline & $25-49$ & 38.9 & 38.6 & 38.2 & 37.8 & 37.6 & 37.2 & 36.9 & 36.5 & 36.3 & 36.2 \\
\hline & $50-65$ & 14.7 & 15.1 & 15.5 & 16.0 & 16.4 & 16.8 & 17.2 & 17.5 & 17.8 & 18.0 \\
\hline & $65+-$ & 9.1 & 9.3 & 9.5 & 9.7 & 9.9 & 10.2 & 10.5 & 10.8 & 11.2 & 11.5 \\
\hline
\end{tabular}

Legend: -- = not available 
$-9-$

Table 5. Percentage share of age groups in active population

\begin{tabular}{|c|c|c|c|c|c|c|c|c|c|c|c|}
\hline & age & $\begin{array}{c}1980 \\
\% \\
\end{array}$ & $\begin{array}{c}1981 \\
\% \\
\end{array}$ & $\begin{array}{c}1982 \\
\% \\
\end{array}$ & $\begin{array}{c}1983 \\
\% \\
\end{array}$ & $\begin{array}{c}1984 \\
\% \\
\end{array}$ & $\begin{array}{c}1985 \\
\% \\
\end{array}$ & $\begin{array}{c}1986 \\
\% \\
\end{array}$ & $\begin{array}{c}1987 \\
\% \\
\end{array}$ & $\begin{array}{c}1988 \\
\% \\
\end{array}$ & $\begin{array}{c}1989 \\
\% \\
\end{array}$ \\
\hline \multirow[t]{4}{*}{ The Netherlands } & $15-24$ & 21.6 & 22.0 & 21.5 & 21.6 & 21.6 & -- & 20.2 & 22.4 & 22.0 & 21.3 \\
\hline & $25-49$ & 59.7 & 61.0 & 62.1 & 62.2 & 62.2 & -- & 64.6 & 63.1 & 64.5 & 65.3 \\
\hline & $50-65$ & 17.2 & 16.3 & 15.7 & 15.6 & 15.6 & -- & 14.7 & 13.6 & 13.5 & 13.4 \\
\hline & $65+-$ & 0.5 & 0.7 & 0.6 & 0.7 & 0.7 & -- & 0.6 & 1.0 & -- & -- \\
\hline \multirow[t]{4}{*}{ France } & $15-24$ & 17.2 & 16.8 & 16.7 & 16.3 & 16.0 & 15.8 & 15.3 & 13.6 & - & -- \\
\hline & $25-49$ & 60.4 & 61.0 & 61.7 & 62.7 & 63.4 & 64.1 & 65.0 & 66.6 & -- & -- \\
\hline & $50-65$ & 21.0 & 21.0 & 20.7 & 20.1 & 19.6 & 19.2 & 18.9 & 18.9 & - & -- \\
\hline & $65+-$ & 1.4 & 1.2 & 0.9 & 0.9 & 0.9 & 0.9 & 0.9 & 0.9 & -- & -- \\
\hline \multirow[t]{4}{*}{ (West) Germany } & $15-24$ & 20.6 & 20.8 & 20.7 & 20.8 & 21.1 & 21.2 & 20.9 & 20.2 & 19.5 & -- \\
\hline & $25-49$ & 58.1 & 57.9 & 58.0 & 58.4 & 58.1 & 58.2 & 58.2 & 58.4 & 58.6 & -- \\
\hline & $50-65$ & 19.6 & 19.8 & 20.0 & 19.6 & 19.6 & 19.5 & 19.9 & 20.3 & 21.0 & -- \\
\hline & $65+-$ & 1.6 & 1.5 & 1.3 & 1.3 & 1.2 & 1.1 & 1.0 & 1.0 & 1.0 & -- \\
\hline \multirow[t]{4}{*}{ United Kingdom } & $15-24$ & -- & 21.0 & -- & -- & -- & -- & 22.9 & -- & -- & -- \\
\hline & $25-49$ & -- & 53.3 & -- & -- & -- & -- & 55.3 & -- & -- & -- \\
\hline & $50-65$ & -- & 23.6 & -- & -- & -- & - & 20.3 & -- & -- & -- \\
\hline & $65+-$ & -- & 2.0 & -- & -- & -- & -- & 1.5 & -- & -- & -- \\
\hline \multirow[t]{4}{*}{ Sweden } & $15-24$ & 14.5 & -- & 15.7 & 15.5 & 15.5 & 15.7 & 16.2 & 16.0 & -- & 16.3 \\
\hline & $25-49$ & 58.5 & -- & 58.5 & 59.1 & 59.7 & 60.1 & 60.4 & 61.3 & -- & 61.5 \\
\hline & $50-65$ & 25.3 & -- & 24.2 & 23.9 & 23.5 & 22.9 & 23.4 & 22.7 & -- & 22.1 \\
\hline & $65+-$ & 1.7 & -- & 1.6 & 1.5 & 1.3 & 1.3 & -- & -- & -- & -- \\
\hline \multirow[t]{4}{*}{ Austria } & $15-24$ & 19.7 & 25.4 & 23.3 & 23.5 & 24.6 & 24.1 & 23.9 & 23.7 & 22.7 & -- \\
\hline & $25-49$ & 59.8 & 56.5 & 58.2 & 58.9 & 58.5 & 59.8 & 60.7 & 61.4 & 62.7 & -- \\
\hline & $50-65$ & 19.8 & 17.3 & 17.7 & 17.0 & 16.4 & 15.6 & 14.9 & 14.4 & 14.2 & -- \\
\hline & $65+-$ & 0.7 & 0.8 & 0.8 & 0.6 & 0.5 & 0.5 & 0.5 & 0.4 & 0.4 & -- \\
\hline \multirow[t]{4}{*}{ United States } & $15-24$ & 23.0 & 23.7 & 22.9 & -- & 21.1 & 20.2 & 19.8 & 19.2 & 18.3 & 17.6 \\
\hline & $25-49$ & 54.6 & 55.2 & 56.3 & -- & 58.9 & 58.8 & 60.6 & 61.5 & 61.3 & 61.9 \\
\hline & $50-65$ & 19.3 & 18.4 & 18.1 & -- & 17.6 & 17.1 & 17.0 & 16.8 & 16.4 & 16.4 \\
\hline & $65+-$ & 3.0 & 2.7 & 2.5 & -- & 2.2 & 2.5 & 2.6 & 2.6 & 2.7 & 2.7 \\
\hline \multirow[t]{4}{*}{ Japan } & $15-24$ & 12.4 & 12.3 & 12.2 & 12.4 & 12.4 & 12.3 & 12.5 & 12.6 & 12.7 & 12.9 \\
\hline & $25-49$ & 61.6 & 61.3 & 60.9 & 60.1 & 59.8 & 59.3 & 58.6 & 58.1 & 57.5 & 57.1 \\
\hline & $50-65$ & 21.0 & 21.4 & 22.0 & 22.5 & 22.9 & 23.4 & 23.8 & 24.2 & 24.6 & 24.6 \\
\hline & $65+-$ & 4.9 & 5.0 & 5.0 & 5.0 & 5.0 & 5.0 & 5.0 & 5.1 & 5.3 & 5.4 \\
\hline
\end{tabular}

Source: ILO/OECD/ROA

Legend: -- = not available 
$-10-$

Table 6. Development of the dependency rate in 7 industrial countries

\begin{tabular}{lllllllll}
\hline & $\begin{array}{l}1950 \\
\%\end{array}$ & $\begin{array}{l}1960 \\
\%\end{array}$ & $\begin{array}{l}1970 \\
\%\end{array}$ & $\begin{array}{l}1980 \\
\%\end{array}$ & $\begin{array}{l}1990 \\
\%\end{array}$ & $\begin{array}{l}2000 \\
\%\end{array}$ & $\begin{array}{l}2010 \\
\%\end{array}$ & $\begin{array}{l}2020 \\
\%\end{array}$ \\
\hline The Netherlands & 58.9 & 63.9 & 59.9 & 51.1 & 44.9 & 47.0 & 46.8 & 53.2 \\
France & 51.7 & 61.3 & 60.5 & 56.9 & 51.2 & 53.3 & 51.3 & 57.9 \\
(West) Germany & 48.6 & 47.5 & 57.1 & 50.8 & 43.8 & 48.7 & 52.9 & 56.4 \\
United Kingdom & 49.4 & 53.7 & 59.2 & 56.2 & 52.4 & 53.3 & 50.7 & 54.8 \\
Sweden & 50.8 & 51.4 & 52.7 & 56.0 & 54.8 & 55.7 & 55.3 & 60.7 \\
United States & 54.0 & 67.4 & 61.4 & 51.1 & 51.6 & 49.3 & 47.4 & 55.3 \\
Japan & 67.8 & 56.1 & 45.1 & 48.4 & 43.2 & 48.8 & 58.4 & 63.9 \\
\hline
\end{tabular}

Source: United Nations/ROA; 1991

Figure 1. Dependency rate in the 12 EC member states: 1985, 2025
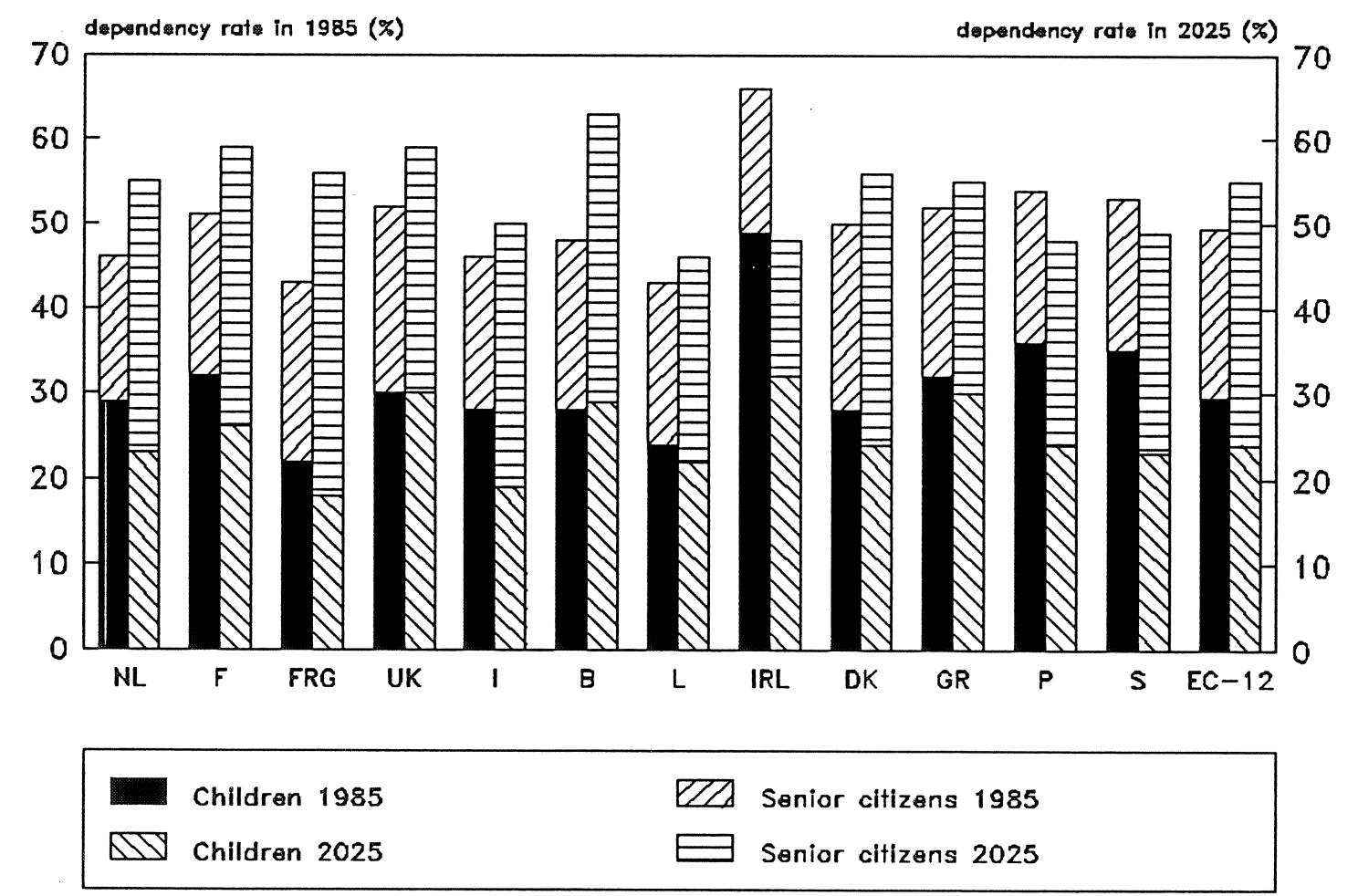

Source : Eurostat 


\subsection{Educational efforts}

\subsubsection{Proportion of the potential labour force in post-elementary education}

Schooling is an important mean to respond to technological progress. The Labour Force Survey conducted yearly by the European Community produces data on the respondents' participation in schooling during the four weeks preceding the survey. Persons between the ages of 15 and 50 are asked to state what schooling they were participating in and for what purpose. From these data we can derive what proportion of the potential labour force between the ages of 15 and 50 participates in schooling. This indicator can be calculated in a narrow and in a wide sense. By schooling in the wide sense is understood 'on-the-job training, apprenticeship, dual system' and 'other training'. So, the indicator encompasses all types of schooling that are combined with a job (see table 7). The indicator in the narrow sense (see table 8), on the contrary, is limited to 'on-the-job training', leaving out the more elementary occupational types of training (apprenticeship etc.). To calculate the indicators, the number of people who participated in schooling in the four weeks before the survey have been related to the total population in the age brackets between 15 and 49 . These indicators can be counted as measures of the scientific and technological breeding ground for, in particular, the diffusion of technological advance.

Table 7. Participation in schooling of the potential labour force between the ages of 15 and 49 (in the wide sense)

\begin{tabular}{|c|c|c|c|c|c|c|c|}
\hline & $\begin{array}{c}1983 \\
\% \\
\end{array}$ & $\begin{array}{c}1984 \\
\% \\
\end{array}$ & $\begin{array}{c}1985 \\
\%\end{array}$ & $\begin{array}{c}1986 \\
\%\end{array}$ & $\begin{array}{c}1987 \\
\%\end{array}$ & $\begin{array}{c}1988 \\
\% \\
\end{array}$ & $\begin{array}{c}1989 \\
\% \\
\end{array}$ \\
\hline The Netherlands & 5 & -- & 5 & -- & 6 & 7 & 7 \\
\hline (West) Germany & -- & 5 & 7 & 8 & 8 & 9 & 8 \\
\hline United Kingdom & 7 & 7 & 7 & 7 & 8 & 9 & 10 \\
\hline Italy & 1 & 1 & 1 & 1 & 2 & 2 & 2 \\
\hline Belgium & 2 & 2 & 2 & 2 & 2 & 1 & 2 \\
\hline Luxemburg & 3 & 3 & 3 & 3 & 3 & 3 & 2 \\
\hline Ireland & 3 & 3 & 3 & 3 & 3 & -- & 3 \\
\hline Denmark & -- & 13 & 15 & 15 & 16 & 14 & 10 \\
\hline Greece & 1 & 1 & 1 & 1 & 1 & 1 & 1 \\
\hline
\end{tabular}

Source: Eurostat/ROA

Table 7 shows that participation in schooling in the wide sense is highest in Denmark and the United Kingdom, followed by West Germany and the Netherlands. It is extremely low in the other countries, especially Greece. In most countries, the level of participation was more or less constant in the 1983-1989 period; in the United Kingdom a rising tendency can be perceived. The decline in Denmark that started in 1988 continues in 1989.

Table 8 represents participation in schooling in the narrow sense, only 'on-the-job training' being considered. The pattern of this indicator largely coincides with that of the wide indicator, although the participation in the narrow sense amounts to only one to three percent. Also with regard to this indicator Denmark and the United Kindom come first, but now followed by the 
$-12-$

Netherlands and Ireland. A striking feature is the relatively low participation in schooling in West Germany (a country known specifically for its well-developed initial dual education).

Table 8. Participation in schooling of the potential labour force between the ages of 15 and 49 (in the narrow sense)

\begin{tabular}{lccccccc}
\hline & $\begin{array}{c}1983 \\
\%\end{array}$ & $\begin{array}{c}1984 \\
\%\end{array}$ & $\begin{array}{c}1985 \\
\%\end{array}$ & $\begin{array}{c}1986 \\
\%\end{array}$ & $\begin{array}{c}1987 \\
\%\end{array}$ & $\begin{array}{c}1988 \\
\%\end{array}$ & $\begin{array}{c}1989 \\
\%\end{array}$ \\
\hline The Netherlands & 2 & - & 2 & -- & 2 & 2 & 2 \\
West) Germany & -- & 0 & 0 & 0 & 1 & 1 & 1 \\
United Kingdom & 1 & 2 & 2 & 2 & 2 & 2 & 3 \\
Italy & 0 & 0 & 0 & 0 & 0 & 0 & 0 \\
Belgium & 1 & 1 & 1 & 1 & 1 & 0 & 0 \\
Luxemburg & 1 & 0 & 0 & 0 & 1 & 1 & 1 \\
Ireland & 2 & 2 & 2 & 2 & 2 & 0 & 2 \\
Denmark & 2 & 2 & 3 & 4 & 3 & 4 & 3 \\
Greece & 0 & 0 & 0 & 0 & 0 & 0 & 0 \\
\hline
\end{tabular}

Source: Eurostat/ROA

The indicators presented here do permit comparison with other countries, but for the time only with the member states of the European Community.

\subsubsection{Proportion of apprenticeships in the labour volume of industrial sectors}

This subsection describes a new indicator which shows the percentage of either primary (table 9) or secondary (table 10) apprenticeships for each industrial sector. This new indicator is calculated on the basis of (1) the numbers of primary apprenticeships for each training structure in the apprenticeship system (supplied by the training institutions) which are collected by the Central Bureau of Statistics, and (2) the data on the labour volume for each industrial sector supplied by the Central Planning Bureau (CPB) every year (Central Economical Plan 1990). In calculating apprentices' share in the labour volume an apprenticeship is considered as a job in which one works for $80 \%$ of a five-day labour week, since apprentices spend one day per week in school. Therefore the number of apprenticeships has been multiplied by the labour hour factor of 0.8 .

The indicator has been calculated for seven sectors, defined by the Central Organ of the Regional Organs for the apprenticeship system (CORO). The labour volume for each sector is determined by adding the labour volumes of a number of corresponding CPB industrial sectors. The number of primary apprenticeships for each sector is determined by aggregating the primary apprenticeships of various training institutions. The numbers in the table represent the percentage of the labour volume in each sector which is supplied by employees with a primary apprenticeship agreement.

Appendix 1 shows which of the industrial sectors defined by the CPB, and which training institutions from the CBS data, are linked to the sectors defined by the CORO. 
Table 9 shows that the share of primary apprenticeships is clearly highest in the metals and electrical sectors, followed by the foodstuffs sector. All sectors show an increase of the number of primary apprenticeships in the eighties. This increase is smallest in the printing sector and largest in the foodstuffs sector and the metals and electrical sectors.

Table 9. Percentage share of primary apprenticeships in labour volume of industrial sectors

\begin{tabular}{lllllllll}
\hline Sector & 1965 & 1970 & 1975 & 1980 & 1985 & 1986 & 1987 & 1988 \\
\hline & & & & & & & & \\
& & & & & & & & \\
Metals and electrical & 6.4 & 5.8 & 3.7 & 5.1 & 5.0 & 6.2 & 7.0 & 7.0 \\
Building and wood & 2.6 & 2.0 & 0.9 & 1.9 & 1.9 & 2.2 & 2.3 & 2.4 \\
Foodstuffs & 1.9 & 2.1 & 1.9 & 2.9 & 3.4 & 3.7 & 4.0 & 4.4 \\
Process technologies & 0.5 & 0.6 & 0.5 & 0.9 & 1.4 & 2.2 & 2.0 & 1.8 \\
Printing & 2.6 & 2.0 & 0.7 & 1.6 & 1.2 & 1.5 & 1.8 & 1.8 \\
Transport & 0.2 & 0.1 & 0.2 & 0.3 & 0.5 & 0.6 & 0.6 & 0.7 \\
Textiles and clothing & -- & 1.0 & 0.7 & 0.9 & 1.8 & 2.2 & 2.1 & 2.2 \\
\hline
\end{tabular}

Source: CBS/CPB/ROA; 1991

Legend: -- not available

Table 10 gives the share of secondary apprenticeships in each industrial sector. The general picture here broadly corresponds with that of the primary apprenticeships.

Table 10. Percentage share of secondary apprenticeships in labour volume of industrial sectors

\begin{tabular}{|c|c|c|c|c|c|c|c|c|}
\hline Sector & 1965 & 1970 & 1975 & 1980 & 1985 & 1986 & 1987 & 1988 \\
\hline Metals and electrical & 0.2 & 0.6 & 0.6 & 1.3 & 1.4 & 1.8 & 2.2 & 2.6 \\
\hline Building and wood & 0.6 & 0.6 & 0.4 & 0.4 & 0.6 & 0.7 & 0.8 & 0.9 \\
\hline Foodstuffs & 0.9 & 0.6 & 0.6 & 1.4 & 1.3 & 1.6 & 1.8 & 2.0 \\
\hline Process technologies & -- & 0.1 & 0.0 & 0.1 & 0.0 & 0.1 & 0.6 & 1.1 \\
\hline Printing & -- & -- & 0.2 & 0.3 & 0.2 & 0.3 & 0.6 & 0.6 \\
\hline Transport & 0.0 & 0.0 & 0.0 & 0.0 & 0.0 & 0.0 & 0.0 & 0.0 \\
\hline Textiles and clothing & 0.1 & 0.0 & 0.0 & 0.0 & 0.2 & 0.1 & 0.1 & 0.2 \\
\hline
\end{tabular}

Source: CBS/CPB/ROA; 1991

Legend: -- not available 


\section{RESPONSE FROM ASSOCIATED INSTITUTES AND COMPLEMENTARY DATA SOURCES}

\subsection{Mailing and response from the network}

As in the previous year, an English version of the report on research carried out in 1990 was sent to sixty research institutes, research sections of departments and individual researchers in foreign countries. It was accompanied by a request to comment on the 1990 report and a request to send figures or reports that could be significant for a new inventory. This year Eurostat was asked for the addresses of users of a number of variables from the Labour Force Survey and, in addition to the institutes that were approached a year ago, these researchers were also approached with a detailed request for information.

Although we again received a great number of reactions to this mailing, its immediate usefulness for inclusion in METING was disappointing. Appendix II gives an overview of the publications received from each country and institute. It shows that there is an institute that focuses on problems in the field of education, training, the labour market and the labour force in almost every country approached. Unfortunately there appears to be little potential for combining the data from these institutes. This would explain why there are still relatively few figures available at European and OECD level on these topics.

\subsection{European institutes and the integration of data collection}

There are several institutes working at European or at some other international level, with international comparisons of national data, which is to say, with making the data comparable.

- The European Centre for the Development of Vocational Training (CEDEFOP) in Berlin, an official organ of the European Commission, has the task of contributing to the development of vocational training types in Europe, through research and consultation. In 1990 a so-called 'Flash' appeared in which the results of a number of countries' studies were compared, creating a reasonably comparable review of the costs of and the participation in company training. Regrettably there has thus far been no sequel to this first Flash, although this will be worked on.

- SYSDEM, the European System of Documentation on Employment, has existed since 1990. SYSDEM was established by the English bureau Ecotec on the authority of the European Commission (DG-V). By means of a quarterly magazine, it gives information on the development of (aspects of) employment in the EC member states. The information is obtained from national correspondents. However reciprocal comparisons of the information supplied are thus far impossible.

- The Mutual Information System on Employment Policies (MISEP) has the same structure as 
SYSDEM. Information on the employment policies of EC member states is given through the quarterly magazine InforMISEP.

- In 1992 the International Association for the Evaluation of Educational Achievement (IEA) will start on the Third International Mathematics Study. The results of the second research project were described in Van Dam and De Grip (1990). The Dutch research will be coordinated through the Faculty of Applied Pedagogy of the University of Twente. In 1994 the International Foreign Languages Project will start. Coordination of the entire project will probably be in the hands of the University of Amsterdam.

- Within the Bureau for Statistics of the European Communities (EUROSTAT), Department E-1: Statistiques d'Emploi et Chomage, Education et Formation, is charged with the development of studies and corresponding protocols, classifications etc., in the field of the labour market, training and the labour force. The execution of these studies is in the hands of the national Bureaus for Statistics of the member states. As yet, only the Labour Force Survey is conducted annually (as of 1992 with the addition of some new variables). The development of common training statistics is still stalemated with the need for a manageable training classification.

Eurostat has now also made a start with the development of forecasts for population, the labour force, and the labour market. They have made an inventory of the institutes in the member states which draw up the corresponding national and regional forecasts. In practically every country of the European Community the forecasts of the labour force are formulated by a government or quasi-government body. Eurostat will at first focus on the harmonization and formulation of population forecasts. Labour supply forecasts will be formulated in a second phase. The forecasts are expected to be formulated on a biannual basis with a forecasting period of thirty years and will appear in three versions. The proposals relating to this were presented and discussed at a Eurostat congress in the autumn of 1991.

\subsection{Incidental surveys}

\subsubsection{Command of foreign languages}

As a result of European integration there is an increasing need for foreign language skills. At the same time the Netherlands appear to be loosing their international reputation in this field.

In order to map the developments in the command of foreign languages, five indicators were devised. These should give a better insight into the actual command of languages and the need for foreign language skills. The problem here is that it is difficult to measure the need for the command of languages, and there are also hardly any data available on actual language proficiency (Van Hest et al., 1990). Moreover, the indicators should be calculated for more than one country and over several years, to be able to make some meaningful statements on the changes in the 'competitive position' of the Netherlands. It is at present possible to calculate 
five indicators, although it will not be possible to update these:

1. The volume of Dutch exports by language regions.

2. The (alleged) need for a command of foreign languages in Dutch businesses.

3. The usage of English, German and French by businessmen with foreign contacts.

4. The reported problems within Dutch business circles regarding the use of foreign languages.

5. The number of languages which the populations of the various European countries learn and can speak correctly.

Table 11. Dutch exports, divided by language regions (percentages)

\begin{tabular}{lcc}
\hline Language region & $\begin{array}{c}\text { Percentage shares in the export in } \\
1977 \\
\%\end{array}$ & $\begin{array}{c}1987 \\
\%\end{array}$ \\
\hline & 33 & 30 \\
German-speaking regions & 19 & 19 \\
French-speaking regions & 8 & 8 \\
Latin regions & 14 & 18 \\
English-speaking regions & 26 & 25 \\
Other regions (incl. Flanders) & & \\
\hline
\end{tabular}

Source: Hest (1990), page 168

The first indicator concerns Dutch exports to various language regions. Table 11 shows that the German-speaking regions are our main export partners. Therefore it seems justifiable to consider German the most important language, at least in so far as business contacts are concerned. The figures on the need for foreign languages mentioned by companies somewhat contradict this conclusion. Obviously companies need foreign language skills for purposes other than just international business contacts. This second indicator is represented in table 12 .

Table 12. Need for foreign languages in Dutch enterprises (percentages)

\begin{tabular}{lrr} 
& $\begin{array}{r}1978 \\
\%\end{array}$ & $\begin{array}{r}1988 \\
\%\end{array}$ \\
\hline English & 64 & 89 \\
French & 49 & 53 \\
German & 65 & 64 \\
Spanish & $(-)$ & 19 \\
Other language & 11 & 5 \\
Number of enterprises & 641 & 231 \\
\hline
\end{tabular}

* Figures in reply to the question: 'Which foreign languages does your enterprise need?'

(-) Rated under 'Other language'

Source: Koster (1990), page 3 
Table 12 shows that the need for English and Spanish has increased very strongly, whereas the need for German and French has remained relatively constant. The increase in the need for foreign language skills has also been established by Advisory Bureau Claessens, which every year examines the job requirements in personnel advertisements. From these studies it appears that the percentage of advertisements in which a command of foreign languages is a requirement rose from $20 \%$ in 1987 to $27 \%$ in 1989 .

Table 13a. Percentage of businessmen with some degree of mastery of English, French or German

\begin{tabular}{lcrr}
\hline & $\begin{array}{c}\text { English } \\
\%\end{array}$ & $\begin{array}{c}\text { French } \\
\%\end{array}$ & $\begin{array}{c}\text { German } \\
\%\end{array}$ \\
\hline The Netherlands & 79 & 20 & 40 \\
France & 27 & 100 & 5 \\
(West) Germany & 32 & 15 & 100 \\
United Kingdom & 100 & 8 & 4 \\
Italy & 23 & 20 & 40 \\
Spain & 20 & 18 & 2 \\
& & & \\
\hline
\end{tabular}

Source: European Businessman Readership Survey 1984, in: VU-Talencentrum (1990)

Table 13b. Percentage shares of English, French and German in the languages mastered, to some degree, by businessmen

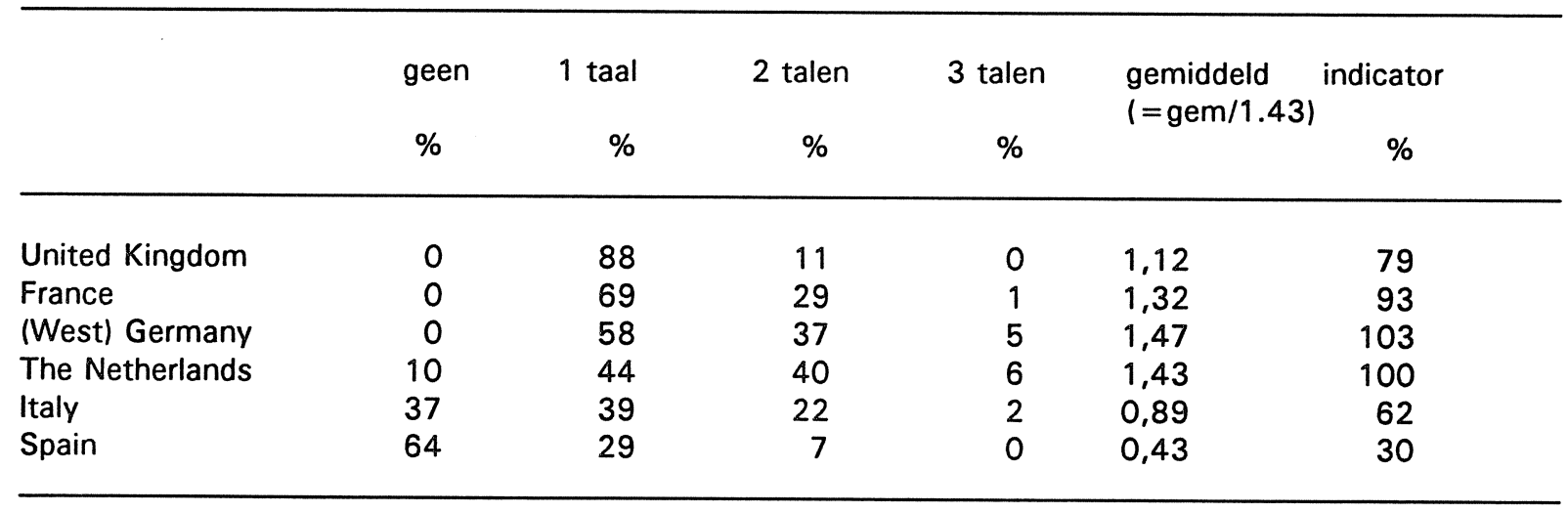

Source: ROA/European Businessman Readership Survey 1984, in: VU-Talencentrum (1990)

The third indicator is represented in table 13. In a number of countries research was carried out among businessmen with international contacts, to see if they could express themselves to some extent in the three main business languages of the European Community: English, German and French. It should be kept in mind that the English, French and Germans do have a natural advantage in international trade, since they can use their mother tongues. Of these three nations, the West Germans most often have a foreign language (see table 13a). Of the other nations, the Dutch can most often express themselves in French, German or English, while the Spanish can do this the least often. The number of languages mastered (of French, German or 
English) is represented in table $13 b$, which shows that Dutch businessmen do very well in this aspect. The column with indicators reveals that only West Germany has a better score than the Netherlands. Compared to the Dutch, West German businessmen have the advantage that their mother tongue is one of the three most important business languages within Europe. Spain scores very badly.

The fourth indicator is represented in table 14. For each foreign languages, increasing problems in speech and writing are observed. The problems concerning fluency of expression in speaking and writing are observed most in French, but there is a strong increase of problems in German and English in the period 1978-1988.

Table 14. Problems experienced in Dutch enterprises in using English, French and German (percentages)

\section{8}

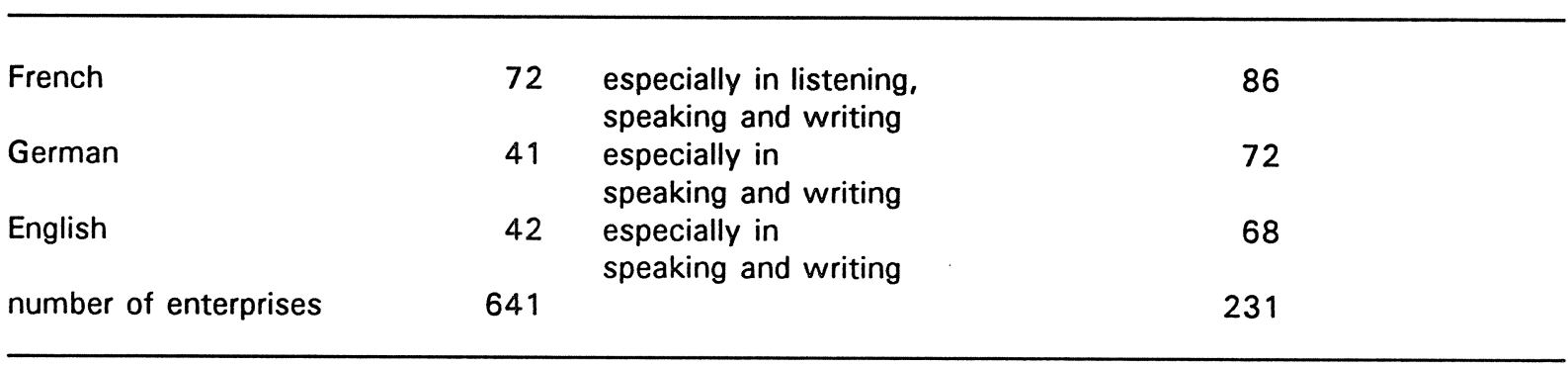

Source: Koster (1990), page 7

1988 . 
$-19-$

Table 15. Number of foreign languages learned at school and correctly spoken

\begin{tabular}{lcccc}
\hline & $\begin{array}{c}\text { Languages } \\
\text { learned }\end{array}$ & $\begin{array}{l}\text { Youth } \\
\text { Languages } \\
\text { correctly } \\
\text { spoken }\end{array}$ & $\begin{array}{l}\text { Entire population } \\
\text { Languages } \\
\text { learned }\end{array}$ & $\begin{array}{l}\text { Languages } \\
\text { correctly } \\
\text { spoken }\end{array}$ \\
\hline The Netherlands & 2.6 & 1.6 & 2.1 & 1.3 \\
France & 1.8 & 0.7 & 1.1 & 0.4 \\
(West) Germany & 1.4 & 0.9 & 0.9 & 0.5 \\
United Kingdom & 1.2 & 0.4 & 0.8 & 0.3 \\
Luxemburg & 3.1 & 2.7 & 2.7 & 2.4 \\
Denmark & 2.5 & 1.4 & 1.9 & 1.0 \\
Belgium & 2.0 & 1.0 & 1.4 & 0.9 \\
Ireland & 1.5 & 0.4 & 0.9 & 0.3 \\
Portugal & 1.4 & 0.6 & 0.7 & 0.4 \\
Italy & 1.3 & 0.5 & 0.8 & 0.3 \\
Spain & 1.1 & 0.6 & 0.6 & 0.4 \\
Greece & 1.0 & 0.7 & 0.6 & 0.4 \\
EC12 & 1.5 & 0.7 & 1.0 & 0.5 \\
\hline
\end{tabular}

Source: Wordelmann (1991), page 34

\section{The Future}

Although the amount of training in foreign languages (indicated by the number of foreign languages learned) has increased in the Netherlands, oral fluency in foreign languages lags behind. The extent to which the Netherlands can maintain its traditional leading position in the language skills depends on the attention given to the quality of foreign language teaching.

\subsubsection{Unemployment and participation in education among young people in Europe}

The German Institut für Arbeitsmarkt- und Berufsforschung (IAB) has gathered data on the unemployment and participation in education for various younger age groups in the European community (IAB, 1990).

\section{Participation in education of young people}

Figure 2 gives the EC figures for the participation of young people in regular education. The relatively strong participation in West Germany, Denmark and the Netherlands can be seen. The training rate for Dutch 24 year olds, at $9.1 \%$, does not differ significantly from the European average of $9.4 \%$. The accompanying text by the IAB does not explain why the figures for 21 and 24 year olds in the United Kingdom are missing. 
Figure 2. Percentage shares of age groups in education in the EC

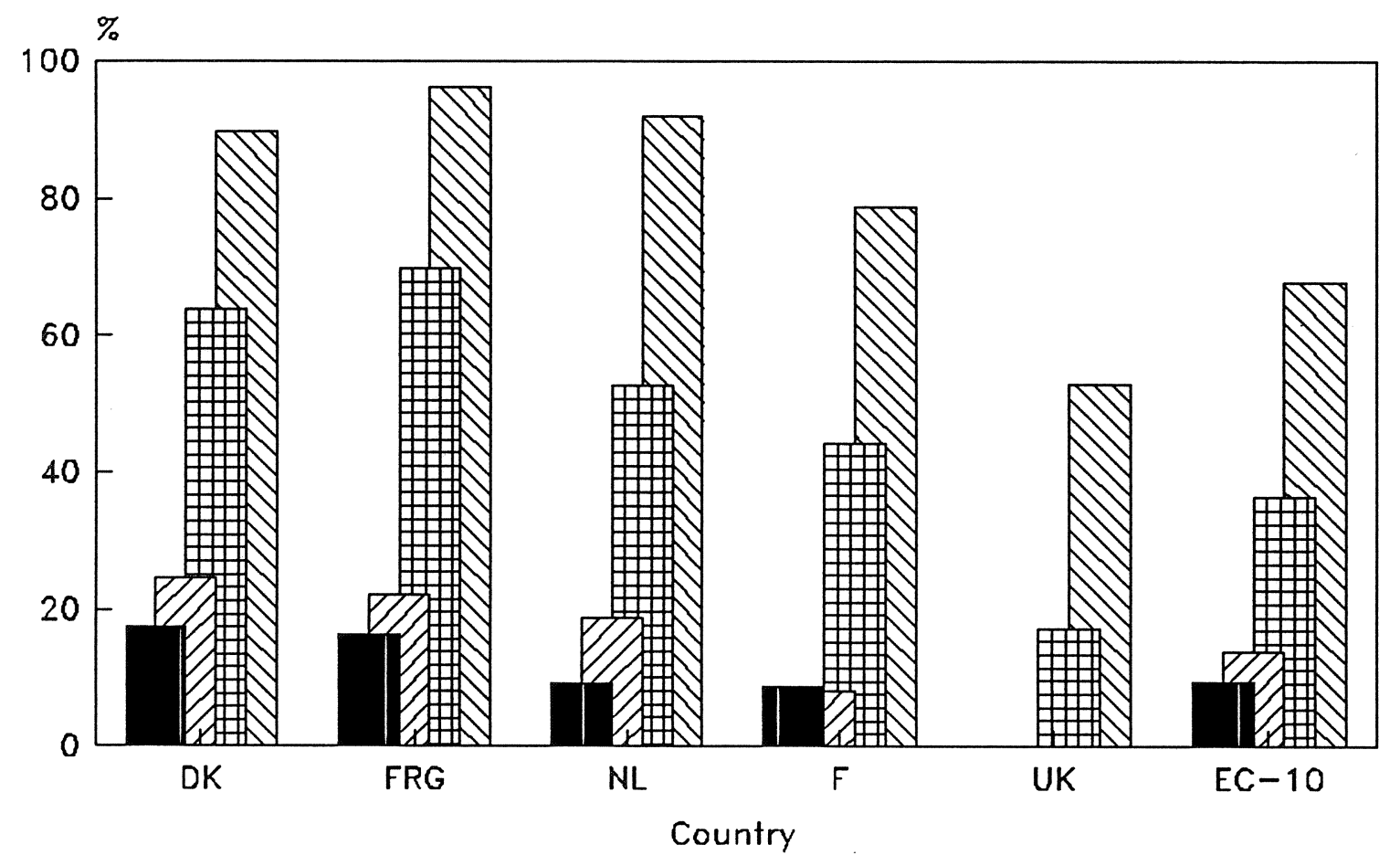

124 years $Z 27$ years 218 years $\$ 116$ years

Source : (West) Germany: IAB/BGR; for the other countries European Commission (1988)

IAB : Institut für Arbeitsmarkt und Berufsforschung

BGR : Bildungsgesamtrechnung

Youth unemployment in the EC

In table 16 and figure 3 the EC figures for youth unemployment are presented. These are also taken from the IAB publication mentioned above.

Figure 3 clearly shows that the rate of youth unemployment in the Netherlands in 1985 was among the lowest in Europe. Table 16 also shows that in 1985 slightly more boys than girls were unemployed in the Netherlands, in contrast to most other countries of the European Community, where youth unemployment among girls is considerably higher than among boys. A third observation concerns the relation between youth unemployment and unemployment in the entire population (for which no figures are given here). For years, Dutch unemployment rates have been among the highest in the European Community. This is not at all the case for youth unemployment. 
Table 16. Unemployment rates among 14 to 24 year olds in the EC

\begin{tabular}{lccc}
\hline Country & men & women & total \\
\hline & & & 16.7 \\
The Netherlands & 18.7 & 28.8 & 25.8 \\
France & 22.9 & 17.7 & 9.9 \\
(West) Germany & & 14 & 19.9 \\
- with dual-system students & 8.8 & 15.4 & 23.6 \\
- without dual-system students & 12.8 & 25.8 & 11.5 \\
United Kingdom & 15.1 & 29.8 & 23.9 \\
Belgium & 17.7 & 13.2 & 25.1 \\
Denmark & 10 & 31.7 & 31.7 \\
Greece & 17.5 & 23.4 & 6.5 \\
Ireland & 26.4 & 38.6 & 18.2 \\
Italy & 26 & 6.5 & 48.1 \\
Luxemburg & 6.4 & 16.6 & 50.8 \\
Portugal & 19.6 & 46.1 & \\
Spain & & & \\
\end{tabular}

Figure 3. Unemployment rates among 14 to 24 year olds in the EC

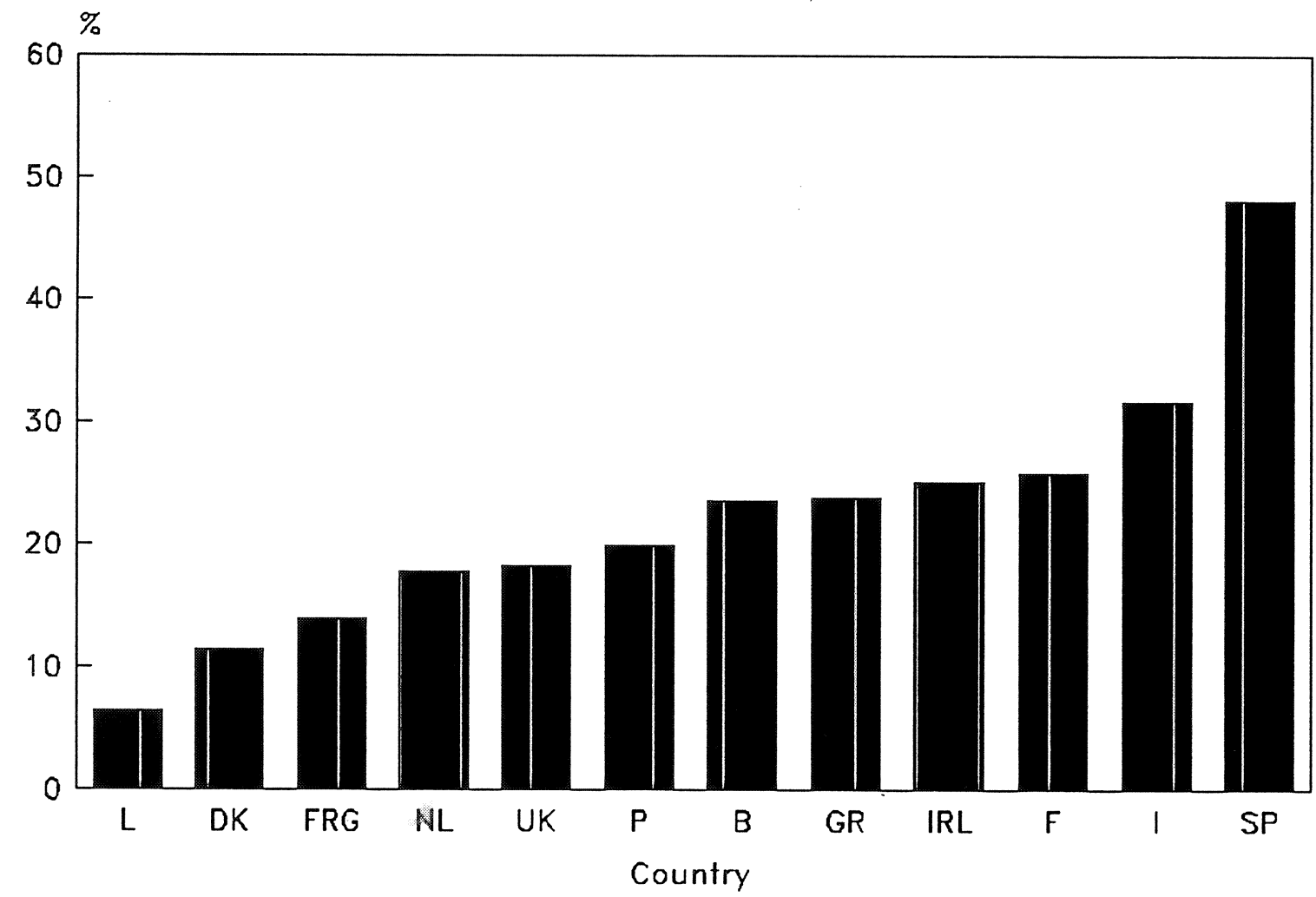

Source : (West) Germany: IAB/BGR; for the other countries: European Commission (1988)

IAB : Institut für Arbeitsmarkt und Berufsforschung

BGR : Bildungsgesamtrechnung 


\subsubsection{IRDAC report on skill shortages in Europe}

The Industrial Research and Development Advisory Committee (IRDAC) of the European Commission has commissioned a report on skill shortages in Europe (IRDAC, 1991). Table 17 was taken from this report.

Table 17. Indicators of the relative importance of engineering and exact sciences in university education and the proportion of engineers in active population

\begin{tabular}{|c|c|c|c|c|}
\hline & $\begin{array}{l}\text { Proportion of } \\
\text { engineering disciplines } \\
\text { in university education } \\
\text { (\% students) }\end{array}$ & $\begin{array}{l}\text { Proportion of exact } \\
\text { sciences in university } \\
\text { education } \\
\text { (\% students) }\end{array}$ & Total & $\begin{array}{l}\text { Proportion of } \\
\text { engineers in } \\
\text { active } \\
\text { population } \\
\text { (in \%) }\end{array}$ \\
\hline The Netherlands & 16.3 & 12.0 & 28.3 & 1.8 \\
\hline France & 7.1 & 12.9 & 18.7 & 1.2 \\
\hline (West) Germany & 14.1 & 18.1 & 32.2 & 2.2 \\
\hline United Kingdom & 16.7 & 22.8 & 39.3 & 1.0 \\
\hline EUR12 & 15.0 & 13.0 & 28.0 & 1.4 \\
\hline Japan & 21.6 & 3.2 & 24.8 & 2.5 \\
\hline United States & 5.9 & 11.6 & 17.5 & 1.4 \\
\hline
\end{tabular}

Source: IRDAC (1991)

The table, which has only an indicative value, is based on a great number of sources which in general refer to the situation in the early eighties. In interpreting the table, note that the first columns refer only to universities and not to other forms of higher education, such as Fachhochschulen and Higher Education Institutes (i.e., polytechnics). The table makes it clear that there are great differences between the member states. It should be remembered that in some countries engineers and technicians from non-university institutions can make up for part of the difference. The first columns show great differences in the relative shares of the engineering disciplines and the exact sciences within academic education. In all European countries, excepting France and the United Kingdom, the engineering disciplines have a higher share than the exact sciences (this is however balanced by engineering education at the nonuniversity polytechnics in the United Kingdom and by the non-academic technicians in France). The differences between the share of the engineering disciplines and of the exact sciences are nowhere as great as in Japan, however, where there are 6 times as many engineers as exact scientists.

The last column shows the number of engineers (with certificates from universities or higher education institutes) as a proportion of the entire occupational population. We can see significant differences here: some member states have twice as many engineers as other countries. On average, Europe is at about the same level as the United States, but remains very much behind Japan (IRDAC, 1991, p. 37/38). 
As part of the IRDAC report, MERIT has conducted research into possible skill shortages in Europe. The following figure from this research was included on page 20 of the IRDAC report.

Figure 4. Expected demand for educational groups

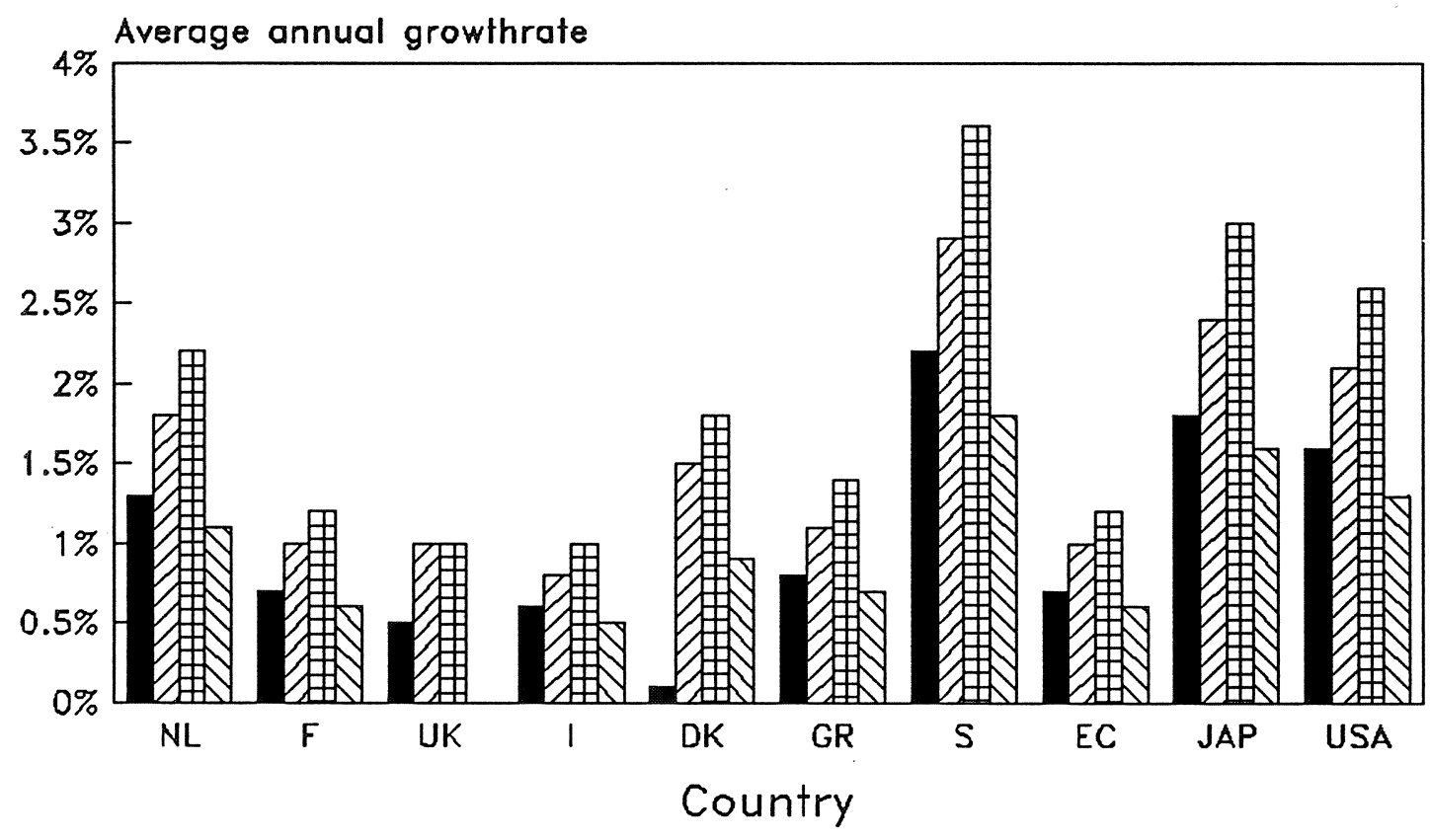

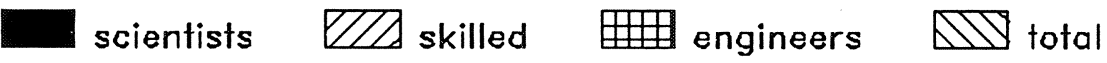

Source : Merit

This diagram gives a clear picture of the expected strong demand for engineers, growing by $1.2 \%$ in Europe, as opposed to growth in the total demand for labour in Europe averaging $0.6 \%$. It should be observed that the expected demand in Europe, with the exception of Spain, is lower than in Japan or the United States.

\subsubsection{Job mobility}

Van Ours (1990 and 1991) has done international comparative research into job mobility. Van Ours compares labour mobility for six countries and tries to explain the observed differences. Table 18 summarises the results regarding mobility from one job to another.

Table 18 shows that there are large differences between the countries considered. Job mobility is lowest in Japan. In the United Kingdom, France and Sweden however, it is considerably higher than in the Netherlands. According to Van Ours it is difficult to explain why the mobility from one job to another is so low in the Netherlands as compared to other countries, with the exception of Japan. 'Maybe the limited job mobility in the Netherlands is simply a characteristic 
of the Dutch labour market, where a high value is attached to a long-term relationship between employer and employees and not to frequent changes of jobs. Perhaps the strongly occupationoriented character of an important part of the Dutch educational system, as a result of which it is not easy to change one's profession once having chosen another, plays a role as well' 6 .

Table 18. Percentage share of workers who change jobs, under high demand, low unemployment, labour market conditions*

\begin{tabular}{lccc}
\hline & $\begin{array}{l}\text { Mobility } \\
\text { from job } \\
\text { to job }\end{array}$ & $\begin{array}{l}\text { Labour force survey } \\
\text { period }\end{array}$ & $\begin{array}{l}\text { Inputdata } \\
\text { Business survey } \\
\text { period }\end{array}$ \\
\hline The Netherlands & 8 & $75-85$ & -- \\
United Kingdom & 14 & $71-87$ & $70-88$ \\
France & 15 & $77-88$ & $75-86$ \\
Sweden & 12 & $72-86$ & $71-87$ \\
Japan & 5 & $71-87$ & - \\
\hline
\end{tabular}

* Basic assumptions: unemployment $=2 \%$; employment growth $=1 \%$ per year

-- = not available

Source: Van Ours (1991), page 16.

Furthermore Van Ours $(1991$, p. 17) concludes that only a limited value should be attributed to the importance of job mobility for the functioning of the labour market and more in particular to the development of unemployment.

6. Van Ours, 1991, p. 16. 


\section{CONCLUSIONS}

On the basis of what we have seen above, the following conclusions can be drawn concerning the data collected this year and the continuation of the METING project.

The yearly updating of the key indicators, of which the results have been given in paragraph 2 , has produced no notable problems this year, with the exception of the forecasts (for the Netherlands) of the proportion of technically trained personnel in the work force. This year two indicators have been added:

- The dependency rate in 7 industrial nations has been calculated on the basis of forecasts by the United Nations (table 6). Since this involves a long-term population forecast (until 2020), yearly up-dating is not necessary. It will be sufficient to up-date the ratio when the UN population forecast is adjusted.

- The percentage of employees with a primary or secondary apprenticeship agreement for each industrial sector (table 9 and 10), calculated on the basis of data from the CBS and CPB. These are provided on a yearly basis, so this (proposed) central indicator can be updated annually.

The mailing to our peer network (intended for the collection of additional, internationally comparable, data) described in section 3 has produced less in the sense of immediate 'hits' than last year. However the response (see appendix 1) shows more clearly the institutes and persons who belong to the 'inner circle' in the field of comparative statistics for the domain that METING covers. From the reactions by mail and by phone it appears that there is little enthusiasm for international cooperation (in the collection of data), since it would entail adapting data files to international standards. This is also the reason why international organizations such as Eurostat, the OECD and UNESCO can still provide little detailed, internationally comparable, data.

Nevertheless, individual researchers and institutes, concentrating on the comparison of one aspect of technology, labour or training, do seem to be able to come up with some internationally comparable data, although this involves a time-consuming study. The collection of interesting publications of that kind throughout the year seems likely to be productive, therefore the motto of METING 1992 could be: keep one finger on the pulse of developments in the international network and, throughout the year, eyes open for any international publications by third parties.

As of 1992, the Maastricht Economic Research Institute on Innovation and Technology (MERIT) will be responsible for maintaining and further expanding the METING databank on the international economic position of the Netherlands with regard to the implementation of technology. ROA's contribution to METING will then be channelled through MERIT. Just as in the past three years, this contribution will relate to that category of indicators within METING which are aimed at the technological potential of the occupational population. This means that ROA will continue to update the present central indicators and will try to broaden and improve the existing key indicators on the basis of a periodic scanning of relevant initiatives from 
international organizations, in order to establish internationally comparable indicators education and employment. 


\section{LITERATURE}

Altena, A.R. van, J. Plantenga, J.J. Schippers, J.J. Siegers (1990), Demografische ontwikkelingen en het functioneren van de arbeidsmarkt: een vergelijkende studie naar het overheidsbeleid in de Bondsrepubliek Duitsland, Frankrijk, Zweden en Nederland, OSA-W73, Den Haag.

Boot, P. (1989), Her- en bijscholing van werkenden, in: Tijdschrift voor politieke economie, $12 \mathrm{e}$ jaargang, nr. 3, januari 1990, p. 93-113.

Braams, M., M. Meesters (1991), Aanpassen en jezelf blijven; Schoolloopbanen en werkervaringen van meisjes met een technische opleiding, OSA W86, Den Haag.

Brouns, M., A. Schokker (1990), Arbeidsvraagstukken en sekse; Trendrapport, Stimuleringsgroep emancipatie-onderzoek, Den Haag.

Brouwer, H. (1990), Nederlandse mogelijkheden voor een Zweeds model?, in: Buitendam, A., e.a. (red), Het Zweedse model; geschikt voor import?, Van Gorcum, Assen/Maastricht.

Centraal Bureau voor de Statistiek (1991, 1990, 1989, 1988, 1987, 1983), Overgangen binnen het onderwijs en intrede in de maatschappij, onderwijsmatrix 1980-1989, Den Haag.

Centraal Bureau voor de Statistiek (), Statistiek van het beroepsonderwijs, 1964-1989.

Centraal Planbureau (1989), Tijdreeksen uit de onderwijsprognose 1989-1, Den Haag.

Dam, J.W. van, A. de Grip (1990), Technologie-indicatoren: bevolking, arbeid en scholing; rapportage 1990, ROA-R-1990/5, Maastricht.

Europa van Morgen, 21 (1991), nr. 26.

Grip, A. de (1987), Onderwijs en Arbeidsmarkt: Scholingsdiscrepanties, Amsterdam.

Grip, A. de, J.A.M. Heijke (1988), Arbeidsmarktindicatoren: een inventarisatie, ROA-W-1988/1, Maastricht.

Grip, A. de, W.J. Nusselder (1989), Technologie-indicatoren met betrekking tot scholing en arbeid, ROA-R-1989/4, Maastricht.

Hest, E., e.a. (1990), Vreemde talen in de markt, Ministerie van Onderwijs en Wetenschappen, Nijmegen.

IAB (1990), M. Tessaring e.a., Bildung und Beschäftigung im Wandel. Die Bildungsgesamtrechnung des IAB. Beiträge zur Arbeitsmarkt- und Berufsforschung 126, Nürnberg.

ILO (1989), Yearbook of Labour Statistics, International Labour Organisation, Geneva.

IRDAC (1991), Kwalificatietekorten in Europa, Industrial Research and Development Advisory Committee, Europese Commissie.

Koster, C. (1990), Behoeften aan vreemde talen, Lezing studiedag Taal en Bedrijf, VUTalencentrum, Amsterdam.

Kuyper, H., M.P.C. van der Werf (1991), De invloed van docenten op sekseverschillen met 
betrekking tot wiskunde, in: Tijdschrift voor Onderwijsresearch, 16 (1991), nr 1, pp. 3-18.

Ministerie van Economische Zaken, Directie ATB (1988), Internationale beleidsvergelijking op het gebied van onderwijs en scholing: het Verenigd Koninkrijk.

Ministerie van Economische Zaken, Directie ATB (1990), Internationale beleidsvergelijking op het gebied van onderwijs en scholing: Bondsrepubliek Duitsland.

Ministerie van Economische Zaken, Directie ATB (1990), METING 2. Indicatoren voor de Technologische positiebepaling van Nederland.

Ministerie van Onderwijs en Wetenschappen (1990), Evaluatie voorlichtingscampagne Kies Exact, Zoetermeer.

Ministry of Labour (1985), The Swedish act on an employee's right to educational leave, Stockholm.

Ministry of Labour (1988), The labour market and labour market policy in Sweden - a discussion paper for the 1990s, Stockholm.

Ministry of Labour, B. Hultgren (1990), Guide : Vocational training system in Sweden, Stockholm.

Neubourg, C. de (1990), Jansen en Jonzon in de jaren tachtig: macro-economische en arbeidsmarktontwikkelingen in Zweden en Nederland, in: Buitendam, A., e.a.(red), Het Zweedse model; geschikt voor import?, Van Gorcum, Assen/Maastricht.

NIPO (1989), Schoolverlatersonderzoek, Amsterdam.

OECD (1991), Economic Outlook July 1991, Organisation for Economic Co-operation and Development, Paris.

Ours, van (1990), Arbeidsmobiliteit in internationaal perspectief', OSA-Voorstudie V-37, Den Haag.

Ours, van (1991), 'Een internationale vergelijking van arbeidsmobiliteit', in: Tijdschrift voor Arbeidsvraagstukken (7), 1991, nr.2, pp. 4-18.

Raadgevend Bureau Claessens (1990), Functie-eisen worden steeds strenger, Utrecht.

Swedish Ministry of Education and Cultural Affairs (1988), Development of education 19861988, National Report of Sweden, Stockholm.

Taakgroep Studentenraming (1990), HO-raming 1990; deel 1: WORSA, Zoetermeer.

UNESCO (1989), Statistical Yearbook, Paris.

Vries, B. de, B. Hövels (1991), Afgesproken! Onderzoek effectiviteit CAO-afspraken over scholing, ITS Nijmegen.

Wordelmann, P. (1991), Fremdsprachen in Ausbildung und Beruf, in: Gewerkschaftliche Bildungspolitik, nr. 2'91.

Wouters, J. (1988), Werkloosheid: vatbaar voor beleid? een vergelijkend onderzoek naar werk loosheid in Nederland, Zweden en Zwitserland, Onderzoeksrapport Erasmus Universiteit Rotterdam, 8811/G, Rotterdam. 
$-29-$

APPENDIX 1. CLASSIFICATION OF INDUSTRIAL SECTORS

\begin{tabular}{||l|l|l||}
\hline CPB sector & CORO sector & $\begin{array}{l}\text { Types of training } \\
\text { distinguished by the CBS }\end{array}$ \\
\hline $\begin{array}{l}\text { base metals industries, } \\
\text { metal production }\end{array}$ & metals and electrical & $\begin{array}{l}\text { metal technologies I to IV, } \\
\text { automobiles, body-work, } \\
\text { and installation techniques }\end{array}$ \\
\hline $\begin{array}{l}\text { Wood and building materials } \\
\text { and the construction } \\
\text { industry }\end{array}$ & building and wood & $\begin{array}{l}\text { construction technology, } \\
\text { woodwork, painting, road } \\
\text { construction and furniture } \\
\text { making }\end{array}$ \\
\hline foodstuffs industry & foodstuffs & foodstuffs technology \\
\hline $\begin{array}{l}\text { chemical and rubber } \\
\text { industries }\end{array}$ & process technologies & $\begin{array}{l}\text { process, measurement and } \\
\text { control technologies }\end{array}$ \\
\hline paper and printing industry & printing & printer's training \\
\hline transportation industry & transport & $\begin{array}{l}\text { harbour and transport } \\
\text { companies, nautical training, } \\
\text { passenger and goods } \\
\text { transport }\end{array}$ \\
\hline $\begin{array}{l}\text { textiles, clothing, leather } \\
\text { and footwear industries }\end{array}$ & textiles and clothing & $\begin{array}{l}\text { textile \& clothing industry, } \\
\text { jewellery and engraving } \\
\text { techniques }\end{array}$ \\
\hline
\end{tabular}




\section{APPENDIX II. PUBLICATIONS RECEIVED, BY COUNTRY}

Once again Germany provided the greatest number of responses, and the most extensive reactions, of all the countries approached. Of the organizations which were approached, a reaction was received from those listed below (with the relevant publications between brackets):

- Statistisches Bundesamt (Jahrbuch 1990; Bevölkerung und Erwerbstätigkeit 1989);

- Deutscher Gewerkschaftsbund (Berufliche Bildung 1990/1991; overnamen uit 'Bildungspolitik');

- Bundesinstitut für Berufsbildung (algemene informatie);

- Deutscher Institutsverlag (algemene informatie);

- Institut für Arbeitsmarkt- und Berufsforschung (Bildung und Beschäftigung in Wandel);

- Institut der Deutschen Wirtschaft (Hochschule-2000; Betriebliche Weiterbildung in der BRD);

- Der Bundesminister für Bildung und Wissenschaft (Berufsbildungsbericht 1990 en -1991; Studenten und Hochschulen 1975 bis 1990; Zahlenbarometer 1990/1991; Grund- und Strukturdaten 1989/1990 en -1990/1991);

Sweden also provided some interesting publications. The number of organizations occupied with the collection and publication of education statistics is however considerably less than in Germany. These are:

- Statistiska Central Byran (Statistica Meddelanden-Education and Training of the Labour Force 1986 and 1987, Integrated Upper Secundary School 1989/1990, Higher Education 1989/1990; Labour Market Tendency Survey for some Training Categories in the Autumn 1990);

- Swedish National Board of Education (Educational and Training Characteristics, School Research Newsletters);

From the United States, the following organizations sent relevant publications:

- US.Department of Education, National Center for Education Statistics (The condition of Education 1991, vol.1 -Elementary and Secondary Education- and vol.2 -Postsecundary Education-);

- US.Department of Labor, Bureau of Labor Statistics (How Workers get their Training, 1985; Occupational Outlook Quarterly, 1988; Employment and Earnings, 1991);

Organizations from the United Kingdom that sent publications:

- The Employment Department Group (algemene informatie);

- Center for Labour Market Studies (algemene informatie);

- Institute of Manpower Studies (Labour Markets and the Developments of People in the 1990's, Annual Report 1989/1990; The European Labour Market Review: the Key Indicators); 
From France, information came from:

- Research Centre for Occupational and Training Analysis (Bilan Formation et Emploi, 1988; Statistique de la Formation Professionelle Continue, financee par les entreprises 1988/1989);

- BIPE-Conseil (Deformation des Structures de I'Emploi: Hausse des Qualifications et Promotions Interne); 